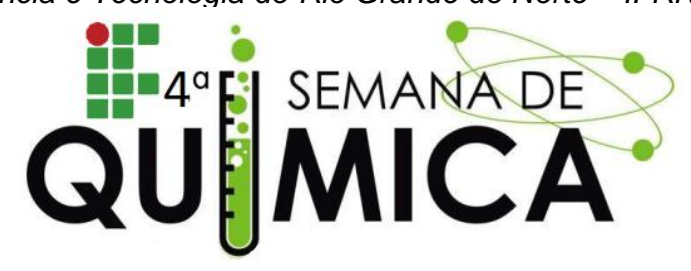

\title{
DETERMINAÇÃO DO ÍNDICE DE ACIDEZ E DO ÍNDICE DE SAPONIFICAÇÃO DE ÓLEO EXTRAÍDO DA POLPA DO FRUTO DO ABACATE (PERSEA AMERICANA)
}

\author{
SILVA, D. M. C. ${ }^{1}$; SOARES, M. L. L. ${ }^{2}$; SANTIAGO JUNIOR, A. F. ${ }^{3}$ e DANTAS, A. N. S. ${ }^{4}$ (IFRN) \\ Instituto Federal do Rio Grande do Norte - Campus Nova Cruz
}

Palavras Chave: óleo do Abacate, índice de acidez, índice de saponificação.

\section{INTRODUÇÃO}

O abacate, fruto do abacateiro (Persea americana), tem seu pico de produção de frutos nos meses de maio a outubro. No Brasil, o fruto maduro é consumido habitualmente com açúcar, mel e licores. Da polpa podem ser extraídos óleos comerciais similares ao óleo de oliva e ao óleo para cosméticos. A casca e o caroço são componentes que possuem teores de lipídios bastante reduzidos, portanto não utilizados para extração de óleo. Cerca de $70 \%$ do peso do fruto corresponde à polpa, que possui grandes quantidades de óleo. Em comparação com outras fontes de óleos vegetais, o óleo de abacate caracteriza-se por apresentar teores elevados de ácidos graxos monoinsaturados. O óleo de abacate assemelha-se muito ao óleo de oliva, pela similaridade de suas propriedades físicoquímicas principalmente pela composição de seus ácidos graxos, predominando em ambos o ácido oléico (ROCHA, 2008).

\section{METODOLOGIA}

Para extração das amostras de óleo foram utilizados cerca de 4 frutos de abacate. Os frutos foram lavados com água corrente, sendo o caroço cuidadosamente separado da polpa. Esta última foi levada para secagem em estufa a uma temperatura de $60{ }^{\circ} \mathrm{C}$ durante cerca de 12 horas. Após esta etapa o óleo bruto foi extraído pelo processo de extração por solvente em Extrator soxhlet. A partir do óleo bruto foram desenvolvidos ensaios para determinação do índice de acidez (INSTITUTO ADOLFO LUTZ, 1985), bem como do índice de saponificação (INSTITUTO ADOLFO LUTZ, 1985).

\section{RESULTADOS E DISCUSSÃO}

Dos frutos obtidos, $66 \%$ corresponde a polpa, cerca de $11 \%$ à casca e $23 \%$ ao caroço. 0 índice de acidez fornece informação sobre o estado de conservação do óleo.
O índice de Saponficação é a quantidade de álcali necessário para saponificar uma quantidade definida de amostra. Expressa o número de miligramas de hidróxido de potássio necessário para saponificar um grama de amostra.

Tabela 1. Índice de acidez e saponificação para as amostras de óleo de abacate.

\begin{tabular}{ccc}
\hline & \multicolumn{2}{c}{ Índice } \\
\hline $\begin{array}{c}\text { Amostr } \\
\text { a }\end{array}$ & $\begin{array}{c}\text { Acidez } \\
\mathbf{( \% )}\end{array}$ & $\begin{array}{c}\text { Saponificação } \\
\left(\mathbf{m g ~ g}^{-1}\right)\end{array}$ \\
\hline $\mathbf{1}$ & 5,85 & 18,3 \\
$\mathbf{2}$ & 5,85 & 11,0 \\
$\mathbf{3}$ & 6,17 & - \\
\hline Média & 5,95 & 14,65 \\
\hline
\end{tabular}

$\mathrm{O}$ teste de acidez por ácido oleico foi realizado em triplicata, o nível de acidez total está em torno de $6,0 \%$. O valor em miligramas encontrado no teste de saponificação foi de $14,65 \mathrm{mg}$.

\section{CONCLUSÃO}

De acordo com os resultados obtidos, pode-se concluir que o óleo extraído, apresenta um valor de acidez acima do permitido pela ANVISA. Para a saponificação o valor encontrado foi satisfatório em relação ao permitido por lei. Em modo geral, podese dizer que o trabalho foi satisfatório, nossos objetivos foram atingidos.

\section{REFERÊNCIAS}

${ }^{1}$ ROCHA T. E. DA S. Composição de ácidos graxos e de fitoesteróis em frutos de quatro variedades de abacate (Persea americana mil). Faculdade de ciências da saúde, programa de pós-graduação em nutrição, Brasília 2008.

2 INSTITUTO ADOLFO LUTZ. Normas analíticas do Instituto Adolfo Lutz. v. 1: Métodos Químicos e Físicos para Análise de Alimentos, 3. ed. São Paulo: IMESP, 1985. p. 247.

3 ANVISA - Agência Nacional de Vigilância Sanitária. Consulta Pública no 85, de 13 de dezembro de 2004. D.O.U de 17/12/2004 